\title{
The assessment of coordination degree between Shandong seaport cluster and regional economy based on Grey Correlation Model
}

\author{
Li Xiaorui
}

\author{
Shandong University (Weihai) Logistics Management, Weihai City, Shandong Province, China \\ Email:623392032@qq.com
}

Corresponding author: Li Xiaorui

Keywords: Shandong, seaport cluster, regional economy, Grey Correlation Model

\begin{abstract}
In this paper, time series data in 2007-2016 are used as samples and Grey Correlation Analysis is used as methods to assess the coordination degree of Shandong port cluster and regional economy. The results show that the development of Shandong port cluster can obviously promote the growth of the hinterland economy and the economic growth will also promote the development of port cluster. Therefore, there is a close interaction and coordination relationship between Shandong port cluster and the regional economic development. Finally, the countermeasures and suggestions for the coordinated development of the port and hinterland areas are put forward, which can be used for the reference for the future development of the two sides.
\end{abstract}

\section{Introduction}

Shandong port cluster is an important part of Bohai Rim port cluster. Its geographical location is superior, its coastline resources are abundant, and the hinterland economy is full of vitality. So, Shandong port cluster have obvious location advantages and huge development potential. In this context, it is necessary to measure the coordination degree of Shandong port cluster and the regional economy, and provide scientific reference and suggestions for healthy development.

\section{Analysis of Shandong port cluster and regional economic development}

\subsection{Analysis of Shandong port cluster development}

Shandong port cluster is the Northeast Asia regional traffic hub, and has the basic conditions for long-term development. Shandong port cluster including Qingdao Port, Yantai Port, Rizhao Port three million tons of the main hub ports, some regional key ports like Weihai Port, Weifang Port, Binzhou Port, Dongying Port, and some general ports like Shidao Port, Rushan Port, Yangkou Port, and so on. Shandong port cluster has nearly 500 productive berths, of which there are nearly 200 berths over ten thousand tons. In 2016, the port throughput of the whole province reached 14.9 hundred million tons, increased by $4.9 \%$. Coastal ports have completed 14.3 hundred billion tons, ranked second in the country and increased by $6.4 \%$. The container throughput was 25 million 90 thousand TEU, increased by $4.45 \%$ and ranked third in the country. Water passenger volume was up to 20 million, flat with the year-ago figure. Water carriage volume was up to 150 million tons, increased by $2.3 \%$.

\subsection{The present situation of Shandong regional economy}

Shandong economic aggregate account for the high proportion of the national GDP, and its annual growth rate is generally higher than the national average. As shown in Table 1, between 2007 and 2016, its GDP has been increasing, indicating that the regional economy developed fast and steady. Therefore, as one of the most dynamic regions of national economy, Shandong has formed an economy entity centered in provincial capitals and focus on big cities, which has a relatively completed spatial structure and development potential. However, the rapid development of 
economy does not mean the coordination and balance of the whole region. The repeated construction and disorder competition still exist. Therefore, how to get rid of the bottleneck and how to take advantage of the interaction and coordinated development between port cluster and regional economy are the key to achieve sound and fast economic development.

\section{Research method}

\subsection{Construction of the index system}

We select indicators that reflect the operation of Shandong port cluster from 2007 to 2016 including Coastal Port Throughput, Container Throughput, Coastal Berth Number, Coastal Berth Length, Waterway Freight Volume and Waterway Freight Turnover. Besides, We select indicators that reflect regional economy development of Shandong Province from 2007 to 2016 including Area GDP, GDP Growth Rate, Per Capita GDP, Total Value of the First Industry, Total Value of the Second Industry, Total Value of the Third Industry, Consumer Price Index (CPI), Retail Price Index (RPI), Urban Employment, the Total Value of Imports and Exports, the Total Value of Imports, the Total Value of Exports, Fixed Assets Investment and the Total Amount of Social Consumable Goods. The original data of each index are shown as follows.

Table1. The operation indicators of Shandong port cluster.

\begin{tabular}{ccccccccccc}
\hline The Year & 2007 & 2008 & 2009 & 2010 & 2011 & 2012 & 2013 & 2014 & 2015 & 2016 \\
\hline $\begin{array}{c}\text { Coastal Port } \\
\text { Throughput[ten } \\
\text { thousand ton] }\end{array}$ & 57547 & 65789 & 73072 & 86421 & 96188 & 106656 & 118138 & 128593 & 134218 & 142855 \\
\hline $\begin{array}{c}\text { Container } \\
\text { Throughput[ten } \\
\text { thousand TEU] }\end{array}$ & 1165 & 1321 & 1312 & 1531 & 1691 & 1899 & 2076 & 2256 & 2402 & 2508 \\
\hline $\begin{array}{c}\text { Coastal Berth } \\
\text { Number[unit] }\end{array}$ & 351 & 440 & 458 & 473 & 485 & 501 & 519 & 540 & 561 & 566 \\
\hline $\begin{array}{c}\text { Coastal Berth } \\
\text { Length[m] }\end{array}$ & 58895 & 71069 & 75453 & 79372 & 82660 & 86787 & 92465 & 97190 & 104048 & 106152 \\
\hline $\begin{array}{c}\text { Waterway Freight } \\
\begin{array}{c}\text { Volume[ten } \\
\text { thousand ton] }\end{array}\end{array}$ & 14625 & 10013 & 13280 & 15633 & 15871 & 13704 & 13478 & 14172 & 14724 & 15060 \\
\hline $\begin{array}{c}\text { Waterway Freight } \\
\text { Turnover[hundred } \\
\text { million ton km] }\end{array}$ & 4048 & 3643 & 3569 & 4083 & 4433 & 2438 & 1212 & 1227 & 1380 & 1587 \\
\hline
\end{tabular}

Reference: The Yearbook of Chinese Port, The Statistical Yearbook of Shandong Province.

Table2. Economic indexes in Shandong Province.

\begin{tabular}{|c|c|c|c|c|c|}
\hline The Year & 2007 & 2008 & 2009 & 2010 & 2011 \\
\hline Area GDP[hundred million yuan] & 25776.91 & 30933.28 & 33896.65 & 39169.92 & 45361.85 \\
\hline GDP Growth Rate & $14.20 \%$ & $12.00 \%$ & $12.20 \%$ & $12.30 \%$ & $10.90 \%$ \\
\hline Per Capita GDP[yuan] & 27604 & 32936 & 35894 & 41106 & 47335 \\
\hline $\begin{array}{l}\text { Total Value of the First Industry } \\
\text { [hundred million yuan] }\end{array}$ & 2509.14 & 3002.65 & 3226.64 & 3588.28 & 3973.85 \\
\hline $\begin{array}{l}\text { Total Value of the Second Industry } \\
\text { [hundred million yuan] }\end{array}$ & 14647.53 & 17571.98 & 18901.83 & 21238.49 & 24017.11 \\
\hline $\begin{array}{l}\text { Total Value of the Third Industry } \\
\text { [hundred million yuan] }\end{array}$ & 8620.24 & 10358.64 & 11768.18 & 14343.14 & 17370.89 \\
\hline Consumer Price Index (CPI) & 104.4 & 105.3 & 100 & 102.9 & 105 \\
\hline Retail Price Index (RPI) & 103.6 & 104.9 & 99.4 & 102.7 & 104.7 \\
\hline Urban Employment[ten thousand] & $\longrightarrow$ & 901.45 & 922.26 & 956.2 & 1050.44 \\
\hline $\begin{array}{l}\text { the Total Value of Imports and Exports } \\
\text { [ten thousand dollars] }\end{array}$ & 122474443 & 158407511 & 139053369 & 189156292 & 235886076 \\
\hline the Total Value of Imports[ten thousand & 47364338 & 65212727 & 59562660 & 84930688 & 110173508 \\
\hline
\end{tabular}




\begin{tabular}{|c|c|c|c|c|c|}
\hline dollars] & & & & & \\
\hline $\begin{array}{l}\text { the Total Value of Exports[ten thousand } \\
\text { dollars] }\end{array}$ & 75110105 & 93194785 & 79490710 & 104225604 & 125712568 \\
\hline $\begin{array}{l}\text { Fixed Assets Investment[hundred million } \\
\text { yuan] }\end{array}$ & 12537.02 & 15435.93 & 19030.97 & 23276.69 & 26769.73 \\
\hline $\begin{array}{l}\text { Total Amount of Social Consumable Goods } \\
\text { [hundred million yuan] }\end{array}$ & 8607.5 & 10658.8 & 12363 & 14620.3 & 17155.5 \\
\hline The Year & 2012 & 2013 & 2014 & 2015 & 2016 \\
\hline Area GDP[hundred million yuan] & 50013.24 & 55230.32 & 59426.59 & 63002.33 & 68024.49 \\
\hline GDP Growth Rate & $9.80 \%$ & $9.60 \%$ & $8.70 \%$ & $8 \%$ & $7.60 \%$ \\
\hline Per Capita GDP[yuan] & 51768 & 56885 & 60879 & 64168 & 68733 \\
\hline $\begin{array}{l}\text { Total Value of the First Industry } \\
\text { [hundred million yuan] }\end{array}$ & 4281.7 & 4565.97 & 4798.36 & 4979.08 & 4929.13 \\
\hline $\begin{array}{l}\text { Total Value of the Second Industry } \\
\text { [hundred million yuan] }\end{array}$ & 25735.73 & 27422.47 & 28788.11 & 29485.9 & 31343.67 \\
\hline $\begin{array}{l}\text { Total Value of the Third Industry } \\
\text { [hundred million yuan] }\end{array}$ & 19995.81 & 23221.51 & 25840.12 & 28537.35 & 31751.69 \\
\hline Consumer Price Index (CPI) & 102.1 & 102.2 & 101.9 & 101.2 & 102.1 \\
\hline Retail Price Index (RPI) & 101.6 & 101.4 & 101 & 100.2 & 101.3 \\
\hline Urban Employment[ten thousand] & 1110.17 & 1290.6 & 1266.34 & 1236.72 & 1215.46 \\
\hline $\begin{array}{l}\text { the Total Value of Imports and Exports } \\
\text { [ten thousand dollars] }\end{array}$ & 245544320 & 266531533 & 276929398 & 240607798 & 234355852 \\
\hline $\begin{array}{l}\text { the Total Value of Imports[ten thousand } \\
\text { dollars] }\end{array}$ & 116835119 & 132341408 & 132220744 & 96682122 & 97259763 \\
\hline $\begin{array}{l}\text { the Total Value of Exports[ten thousand } \\
\text { dollars] }\end{array}$ & 128709205 & 134190125 & 144708654 & 143925676 & 137096088 \\
\hline $\begin{array}{l}\text { Fixed Assets Investment[hundred million } \\
\text { yuan] }\end{array}$ & 31255.96 & 36789.07 & 41599.13 & 48312.44 & 53322.94 \\
\hline $\begin{array}{l}\text { Total Amount of Social Consumable Goods } \\
\text { [hundred million yuan] }\end{array}$ & 19651.9 & 22294.8 & 25111.5 & 27761.4 & 30645.8 \\
\hline
\end{tabular}

Reference: The Statistical Yearbook of Shandong Province.

\subsection{Statistical method}

We choose the Grey Correlation Model put forward by Prof. Deng Julong in 1980s.

Steps of grey correlation calculation are as follows:

The first step: Process the original data dimensionless. The primal transformation method is applied to transform the original number series, and the first data of the same sequence is divided by back original data respectively. Then a new multiple sequences are obtained, which are the initial value sequences. We get the dimensionless data.

The second step: Calculate the correlation coefficient. Set the reference sequence is $\mathrm{X}_{0}$, the comparison sequence (subsequence) is $\mathrm{X}_{\mathrm{i}}$. The reference sequence after data transformation is $\left\{\mathrm{X}_{0}(\mathrm{t})\right\}$, the subsequence is $\left\{\mathrm{X}_{\mathrm{i}}(\mathrm{t})\right\}$. At time $\mathrm{t}=\mathrm{k}$, the correlation coefficient $\mathrm{L}_{0 \mathrm{i}}(\mathrm{k})$ of reference sequence $\left\{\mathrm{X}_{0}(\mathrm{t})\right\}$ and subsequence $\left\{\mathrm{X}_{\mathrm{i}}(\mathrm{t})\right\}$ can be calculated by the formula as follows:

$$
\mathrm{L}_{0 \mathrm{i}}(\mathrm{k})=\frac{\triangle_{\min }+\rho \triangle_{\max }}{\triangle_{0 \mathrm{i}}(\mathrm{k})+\rho \triangle_{\max }}
$$

$\triangle \Delta_{0}(\mathrm{k})$ stands for absolute difference of the two sequence in $\mathrm{k}$ time, that is $\triangle_{0 \mathrm{i}}(\mathrm{k})=\mid \mathrm{x}_{0}(\mathrm{k})$ $\mathrm{x}_{\mathrm{i}}(\mathrm{k}) \mid(1 \leq \mathrm{i} \leq \mathrm{m}) . \Delta_{\max }$ and $\Delta_{\min }$ represent the maximum and the minimum of absolute difference at every moment in all sequences respectively. The $\rho$ is resolution coefficient, $\rho \in(0,1)$. In general, it is 
advisable for $0.1 \sim 0.5$.

The third step: Calculate the coordination degree. The coordination degrees of two sequences are calculated by the average value of two sequences' correlation coefficients.

$$
\mathrm{R}_{0 \mathrm{i}}=\frac{1}{\mathrm{~N}} \sum \mathrm{L}_{0 \mathrm{i}}(\mathrm{k})
$$

$\mathrm{R} 0 \mathrm{i}$ is the coordination degree of subsequence I and reference sequence $\mathrm{o} . \mathrm{N}$ is the number of data.

The fourth step: Rank factors by correlation degree and list the association matrix. There are many factors that affect the social and economic development of the port and hinterland. In this paper, we use grey correlation model to analyze the relationship between port cluster and regional economy in Shandong Province, and determine the main correlation factors between the two, so as to provide a theoretical basis for their coordinated relationship.

\section{Empirical analysis}

The data are derived from The Statistical Yearbook of Shandong Province, The Statistical Bulletin of Shandong Province, The Yearbook of Chinese Port and some other related documents. The operation indicators and economic indicators of main ports in Shandong Province from 2007 to 2016 are selected as samples. Averaging processing is used in each sequence.

Table3. Initialized indicators

\begin{tabular}{|c|c|c|c|c|c|c|c|c|c|c|}
\hline The Year & 2007 & 2008 & 2009 & 2010 & 2011 & 2012 & 2013 & 2014 & 2015 & 2016 \\
\hline $\begin{array}{l}\text { Container } \\
\text { Throughput }\end{array}$ & 0.4441 & 0.5397 & 0.6018 & 0.1674 & 1.0809 & 1.1946 & 1.218 & 1.4213 & 1.5699 & 1.7623 \\
\hline $\begin{array}{l}\text { Coastal Port } \\
\text { Throughput }\end{array}$ & 0.4304 & 0.5143 & 0.4856 & 0.5447 & 0.9541 & 1.0538 & 1.2259 & 1.4423 & 1.5994 & 1.7495 \\
\hline $\begin{array}{c}\text { Coastal Berth } \\
\text { Number }\end{array}$ & 0.7369 & 0.821 & 0.8109 & 0.8546 & 1.0027 & 1.0633 & 1.1171 & 1.1541 & 1.1945 & 1.245 \\
\hline $\begin{array}{l}\text { Coastal Berth } \\
\text { Length }\end{array}$ & 0.5839 & 0.6107 & 0.6793 & 0.7291 & 1.0153 & 1.1341 & 1.2149 & 1.2779 & 1.3405 & 1.4143 \\
\hline $\begin{array}{c}\text { Waterway Freight } \\
\text { Volume }\end{array}$ & 0.4008 & 0.6287 & 0.7943 & 1.0039 & 1.2619 & 0.8639 & 1.1458 & 1.3488 & 1.3694 & 1.3902 \\
\hline $\begin{array}{c}\text { Waterway Freight } \\
\text { Turnover }\end{array}$ & 0.5266 & 0.8766 & 1.0408 & 1.2251 & 1.1536 & 1.0383 & 1.0172 & 1.1635 & 1.2635 & 1.3122 \\
\hline Area GDP & 0.4129 & 0.5135 & 0.6279 & 0.7487 & 0.8812 & 1.0575 & 1.1588 & 1.3391 & 1.5507 & 1.7097 \\
\hline GDP Growth Rate & 1.033 & 1.1786 & 1.1555 & 1.1324 & 1.0939 & 0.9244 & 0.9398 & 0.9475 & 0.8397 & 0.7549 \\
\hline Per Capita GDP & 0.4282 & 0.5297 & 0.6433 & 0.7617 & 0.8909 & 1.0629 & 1.1584 & 1.3266 & 1.5276 & 1.6707 \\
\hline $\begin{array}{l}\text { Total Value of the } \\
\text { First Industry }\end{array}$ & 0.5299 & 0.6364 & 0.7027 & 0.7654 & 0.8979 & 1.0745 & 1.1547 & 1.2841 & 1.4221 & 1.5323 \\
\hline $\begin{array}{l}\text { Total Value of the } \\
\text { Second Industry }\end{array}$ & 0.405 & 0.5295 & 0.6544 & 0.7852 & 0.9147 & 1.0974 & 1.1804 & 1.3263 & 1.4999 & 1.6072 \\
\hline $\begin{array}{l}\text { Total Value of the } \\
\text { Third Industry }\end{array}$ & 0.3937 & 0.4562 & 0.5673 & 0.6881 & 0.8253 & 0.9918 & 1.1267 & 1.3733 & 1.6631 & 1.9145 \\
\hline $\begin{array}{c}\text { Total Amount of } \\
\text { Social Consumable } \\
\text { Goods }\end{array}$ & 0.4366 & 0.4973 & 0.5797 & 0.6785 & 0.8092 & 1.002 & 1.1622 & 1.3744 & 1.6127 & 1.8474 \\
\hline CPI & 0.9843 & 1.0087 & 0.9902 & 0.9834 & 1.0165 & 1.0252 & 0.9736 & 1.0018 & 1.0223 & 0.9941 \\
\hline RPI & 0.9813 & 1.0068 & 0.9853 & 0.9853 & 1.0146 & 1.0274 & 0.9735 & 1.0058 & 1.0249 & 0.9951 \\
\hline Urban Employment & 0.9191 & 0.9367 & 0.9551 & 0.9746 & 0.9944 & 1.0118 & 1.0292 & 1.0468 & 1.0605 & 1.0718 \\
\hline $\begin{array}{l}\text { the Total Value of } \\
\text { Imports and Exports }\end{array}$ & 0.3266 & 0.4445 & 0.5623 & 0.6968 & 0.8967 & 1.1565 & 1.0136 & 1.3818 & 1.7258 & 1.7956 \\
\hline $\begin{array}{l}\text { the Total Value of } \\
\text { Imports }\end{array}$ & 0.3048 & 0.4198 & 0.5163 & 0.6175 & 0.7984 & 1.0949 & 0.995 & 1.4275 & 1.8572 & 1.9686 \\
\hline
\end{tabular}




\begin{tabular}{ccccccccccc}
\hline $\begin{array}{c}\text { the Total Value of } \\
\text { Exports }\end{array}$ & 0.3433 & 0.4634 & 0.5975 & 0.7576 & 0.972 & 1.2037 & 1.0278 & 1.3467 & 1.625 & 1.663 \\
\hline
\end{tabular}

We select the indicators reflecting major ports' performance of operation in Shandong province as the reference sequence, and the economic development of Shandong province as the comparison sequence. According to the calculation steps of grey correlation model, we calculate the correlation coefficient and correlation degree between reference sequence and comparison sequence by formula (1) (2), and get the incidence matrix according to the order of the project.

Table4. The incidence matrix of port cluster operation indicators and economic indicators.

\begin{tabular}{|c|c|c|c|c|c|c|}
\hline Incidence matrix & $\begin{array}{l}\text { Container } \\
\text { Throughput }\end{array}$ & $\begin{array}{c}\text { Coastal } \\
\text { Port } \\
\text { Throughput }\end{array}$ & $\begin{array}{c}\text { Coastal } \\
\text { Berth } \\
\text { Number }\end{array}$ & $\begin{array}{l}\text { Coastal } \\
\text { Berth } \\
\text { Length }\end{array}$ & $\begin{array}{c}\text { Waterway } \\
\text { Freight } \\
\text { Volume } \\
\end{array}$ & $\begin{array}{c}\text { Waterway } \\
\text { Freight } \\
\text { Turnover } \\
\end{array}$ \\
\hline Area GDP & 0.8506 & 0.8875 & 0.6745 & 0.7614 & 0.7326 & 0.7049 \\
\hline GDP Growth Rate & 0.5293 & 0.5211 & 0.5895 & 0.4853 & 0.573 & 0.7912 \\
\hline Per Capita GDP & 0.8428 & 0.8732 & 0.6897 & 0.7783 & 0.7368 & 0.7132 \\
\hline Total Value of the First Industry & 0.7725 & 0.7961 & 0.7435 & 0.8589 & 0.7626 & 0.755 \\
\hline Total Value of the Second Industry & 0.8339 & 0.8539 & 0.6908 & 0.7999 & 0.7463 & 0.7113 \\
\hline Total Value of the Third Industry & 0.8011 & 0.8507 & 0.6189 & 0.6765 & 0.6949 & 0.6736 \\
\hline Total Amount of Social Consumable Goods & 0.8399 & 0.8852 & 0.6219 & 0.7029 & 0.6991 & 0.6819 \\
\hline CPI & 0.5725 & 0.5899 & 0.7222 & 0.5814 & 0.6322 & 0.8045 \\
\hline RPI & 0.5733 & 0.5913 & 0.7249 & 0.5831 & 0.6336 & 0.805 \\
\hline Urban Employment & 0.5904 & 0.6129 & 0.7731 & 0.6058 & 0.6668 & 0.8147 \\
\hline the Total Value of Imports and Exports & 0.8139 & 0.8379 & 0.6015 & 0.6867 & 0.6425 & 0.675 \\
\hline the Total Value of Imports & 0.7541 & 0.8157 & 0.5653 & 0.6151 & 0.6004 & 0.6502 \\
\hline the Total Value of Exports & 0.8364 & 0.8377 & 0.6423 & 0.7288 & 0.6826 & 0.6952 \\
\hline Fixed Assets Investment & 0.7989 & 0.838 & 0.5955 & 0.6753 & 0.6853 & 0.6545 \\
\hline
\end{tabular}

It can be seen from the results that correlation degree between Port Throughput and economic indicators were higher than other indicators of operation except GDP Growth Rate, price index and Employment. What's more, the correlation degree of Port Throughput and Area GDP, the Total Amount of Social Consumable Goods, Per Capita GDP in the correlation matrix won the top three. The correlation degree between Container Throughput and economic indicators is slightly lower than Port Throughput. It can be seen that the Port Throughput has the most prominent role in promoting the economic development of hinterland, and the Container Throughput is the next.

Besides, Area GDP, the Total Amount of Social Consumable Goods and Per Capita GDP have the most obvious driving effect on the operation development of port cluster. Total Value of the Second Industry are closely related to the operation of port cluster, while Fixed Assets Investment and import and export trade play an significant role in driving port development. CPI, RPI, and GDP Growth Rate have a weak interaction with port cluster.

In the macro view, the correlation degrees between the operation development of Shandong port cluster and the economic development were almost higher than 0.6 , reaching a significant correlation. Therefore, we concluded that the development of Shandong port cluster can obviously promote the growth of hinterland economy, while the growth of hinterland economy will also significantly drive the development of port cluster. There is a close interaction and coordination relationship between Shandong port cluster and regional economic development. 


\section{Conclusions and suggestions}

Based on port operation indicators and regional economic indicators, the driving role of port economy to urban economy is studied by using grey relational model, and the promotion role of urban economy to port economy is analyzed. Conclusions are drawn as follows:

1. Shandong port cluster operation indicators increased year by year, Waterway Freight Volume and Waterway Freight Turnover has shifted since April 2012 due to net of Qingdao ocean freight and cargo turnover, eleven indicators of economic development in the hinterland were showed a trend of rising year by year. The development trend was consistent between the two.

2. Shandong port cluster and regional economy have a high correlation. They must coordinate in order to achieve good social and economic benefits.

3. The industry and agriculture in Shandong Province still need to be strengthened, and the port has not been fully utilized.

Under the background of global economic integration, we should not only enhance the driving role of port cluster to the hinterland economy, but also stimulate the promoting role of regional economy to port construction, so as to achieve the goal of common development.

1. Shandong should insist on the principle of outstanding characteristics, unified layout and reasonable planning, strengthening and improving functions of port cluster continuously. The port cluster should determine different functions according to characteristics and advantages of different ports, and achieve a win-win situation and the optimal utilization of resources through differential development strategy. The port area of Shandong province is adjacent to Japan and South Korea, the key to achieve a long-term development is to strengthen cooperation with Northeast Asia, especially Japan and South Korea and participate in international cooperation and competition in a higher level and wider area.

2. Shandong must give full play to the advantages of ports with the strengths of the cities. "Develop ports with cities, use ports for cities" is the guiding ideology of the coordinated development of the port and hinterland. Therefore, when conflicts between ports and cities are confronted with each other, effective measures should be taken to promote benign interaction between ports and cities. Make the port as the core link of the industrial structure; promote the coastal cities' industry, business, trade and financial industry to close to the port, realizing the multi-function of ports and areas nearby.

3. Expand the level of opening to the outside world and promote regional development. Shandong Peninsula Blue Economic Zone has its particularity in location. Its participation in the cooperation and competition of the Northeast Asian economic circle with its "overall strength" means that Shandong regional economy has gained the cooperation and competition opportunities in a higher level and wider field. Shandong peninsula is on the brink of Bohai and the Yellow Sea. It is located in the core area of 10+3 (ASEAN + China, Japan and South Korea) economic circle. It is the forefront of trade between Japan, South Korea and China. Making Shandong Peninsula Blue Economic Zone a leading area for the cooperation with Japan and South Korea, speeding up the process to improve the open, safe and efficient economic system that has a internal and external linkage, win-win mechanism. It is not only conducive to comprehensively improving the level of internationalization of our province's economy, but also has strategic significance.

\section{References}

[1] Hoyle B S, Hilling D. Seaport Systems and Spatial Change: Technology, Industry and Development Strategies [M].Wiley: Chichesterm, 1984.

[2] Cesar Ducruet, Sung-Woo Lee. Frontline soldiers of globalization: Port-urban Evolution and Regional Competition [J].Geo Journal, 2003(67):107-122.

[3] Wang Zhen, Research on competition strategy of Yantai port [D], Shandong University, 2007. 
[4] Wang Tao, Research on the influence of ports on the port cities' economic development [D], Ocean University of China, 2008.

[5] Chen Mengzhu, Evaluation of the effectiveness on port and urban economic development [D], Dalian Maritime University, 2013. 